\title{
Regression and Matching Estimates of the Effects of the Land Certification Program on Rural Household Income in China
}

\author{
Yuepeng Zhou \\ PhD student, School of Business, University of New South Wales, \\ UNSW Canberra, Australia. Email: hermia84@hotmail.com. \\ Satish Chand \\ Professor, School of Business, University of New South Wales, \\ UNSW Canberra, Australia. Email: hermia84@hotmail.com.
}

Doi:10.5901/ajis.2013.v2n8p350

\section{Abstract}

Despite the steady growth of China's economic since the economic reforms in 1978, the rural-urban income inequality has also risen rapidly. Here we explore the role that rural land reform plays in raising income. We investigate growth in rural household income which can be attributed to a Rural Land Registration and Certification (RLRC) program that was put into effect in Chengdu city, Sichuan province in 2009. We draw on household socio-economic data collected in 2011 through a purpose designed survey for the analysis. Using regression and matching methods, we find that the RLRC program has contributed to certified farmers' participation in land market, especially rental transfer of land to more productive producers. Findings for the program's impact on increasing farmers' income are mixed. Although transfer income from land rentals and government subsidies has greatly increased, farming income and wage income have not significantly improved, suggesting that land certification may have had a substitution effect and an income effect on household's choice between farm, wage employment and leisure.

Keywords: rural land certification, household income, propensity score matching, China

\section{Introduction}

The land that the farmers are allocated is among the few resources that they can use to generate incomes, particularly due to limited access to formal sectors employment. Property rights to land are thus one of the most powerful resources available to farmers to increase and extend their sustainable livelihoods (FAO, 2002). While there is a lot of research on the investment and productivity effects of land tenure (Deininger, Ali, \& Alemu, 2011; Dong, 2000; Feder \& Onchan, 1987; S. Holden, Deininger, \& Ghebru, 2009; Place \& Otsuka, 2002), very few quantitative studies focus on the welfare impacts of land reforms.

Land in rural China is an asset that farmers have had access to, but the property rights to this land have remained with the local community collectively. The issue of such rights has the potential to enrich farmers whilst reducing inequality between rural and urban residents. In China, the urban income was about 3.23 times that of the countryside in 2010, so that China has one of the largest urban-rural gaps (Xin He, 2011). To address the issues, consecutive No. 1 policy documents issued by the central government have taken boosting farmers' incomes as the theme (Zhang, 2010). For example, the No.1 document in 2008 regulates that a land certification program should be carried out and farmers would be allowed to transfer their land use rights based on the new land certification. This rural land reform was expected to improve rural living standards and double per capita annual net income by 2020 for China's 700 million farmers - who currently earn 4,760 yuan (less than US $\$ 800$ ) a year on average ${ }^{1}$.

By better protecting property rights through land certification program, the reforms could also help reduce the social tensions and riots that have resulted from corruption within the present system, with property developers conspiring

${ }^{1}$ Data was from National Bureau of Statistics of China 2009, http://www.stats.gov.cn/tjsj/ndsj/. yuan: Chinese unit of currency. 1 USD = 6.28 yuan, 2013-01-30. 
with local officials to illegally seize farmland in exchange for little to no compensation. Of the tens of thousands of rural protests that occur in China annually, nearly half relate to land grabs (Fan, 2008).

Chengdu was in the first wave to pilot this rural land reform which entailed issue of property rights to the land. In this paper, we investigate the impacts of Rural Land Registration and Certification (RLRC) program on rural household income. Section 2 discusses the methodology that will be employed. Section 3 presents the empirical results of the analysis, followed by section 4 to draw the conclusion.

\section{Methodology}

\subsection{Study sites and data collection}

The purpose of the paper is to study the impact of RLRC program on household income. Thus the survey sample was stratified into two groups: (1) Treatment group comprising: households on certified land in Qun'an village, Sichuan province, and (2) Control group comprising: households on uncertified land in Xiayong village, Fujian province. Ideally the treatment and control villages ought to be identical except for certification but this was not the case as explained below.

These two sites were selected in consultation with local government officials. Qun'an village was identified as one of the pilot areas in Chengdu City where a land reform project was on-going in 2011. At the time of survey, the households in Qun'an village had had land certification for about two years. Land issues are sensitive in rural China and it proved impossible to find an uncertified village in Sichuan: officials refused to disclose the list of uncertified areas, describing it as an "internal confidential file". After exhausting all other options, I chose solely for convenience my hometown. Both the villages are located within the main rice producing regions in their counties in south China, and some 50 kilometres via paved road to the main market. As to the uncertified village (Xiayong), although it is located in a mountainous area, the farmers grow crops mainly on the flat plots. All these similarities make the uncertified village a suitable comparison group to the certified village.

With the referral letters from official departments in the counties, I made appointments with the village heads to set up times for the survey. In addition to budget and time constraints, the fact that many household heads work outside villages after the rice harvest made random sampling difficult. The village heads arranged the production team leaders to assist the survey through: (1) recruiting as many household heads as possible to do the questionnaires; and (2) guiding us to visit household heads house by house. All the interviewees were informed of the purpose of the survey and their written consent was sought before the interview. ${ }^{2}$

Data was collected in November 2011, about two months after the rice harvest. The questions focussed on information relating to the socioeconomic characteristics of households; the output of rice; the use of purchased inputs and labour; the tenure status of the land; and household income sources. Data were therefore cross-sectional with responses from 140 households, including 73 from Qun'an village (certified) and 67 from Xiayong village (uncertified). Respondents were usually the household heads except when they were absent, in which case they were mainly replaced by their spouses or other adult household members.

\subsection{Hypotheses}

Research shows that land certification has enhanced tenure security and stimulated land rental market participation (Deininger, et al., 2011; Gine, 2005; Holden, Deininger, \& Ghebru, 2011). Therefore, the titled farmers lacking comparative advantage in agriculture can lease their land to others, take up non-agricultural employment or invest in a business as a source of off-farm income (Chand \& Yala, 2009; de Janvry, Gordillo, Platteau, \& Sadoulet, 2001).

In terms of the relationship between land tenure security and household income, López (1996) cited in Holden (2011)) found a positive return, net of the cost of titling, to household income from land registration and titling in Honduras. Moreover, positive impacts of land registration and titling on both income and land values have been found in Thailand (Feder \& Nishio, 1998). In Nicaragua, receipt of registered title increases land values by 30\% (Deininger \& Chamorro, 2002). Since the rural land registration program has just started in China, there is a void in terms of empirical research on the welfare effects of land titling.

In rural China, farmers have three main sources of income: farm income, wage income, and transfer income.

\footnotetext{
2 The survey was conducted as stipulated in the UNSW ethics approval for this research.
} 
1. Farm income: comprises the potential market value of crops and the sale of livestock. In order to encourage farmers to grow more grains and boost production, since 2004, the central government has set minimum procurement prices for grain, including rice and wheat to buy grains from farmers (ChinaDaily, 2013). At the time of survey, the minimum procurement prices for rice and wheat were 1.2 yuan/jin ${ }^{3}$ and 1 yuan/jin, respectively.

2. Wage income: includes wages received from employment outside of agriculture plus income from selfemployment (entrepreneurship).

3. Transfer income consists of rental income from the land being leased out and government subsidies, such as Cultivated Land Protection Fund (CLPF), available only in Chengdu city.

4. Other income: for example, remittances from children and pension insurance.

In June 2007, Chengdu city was licensed by the state to proceed with a land reform pilot project that would allow farmers to lease out and mortgage their land. The RLRC program was the first step of the reform. The goal of RLRC was to address the problems of land tenure insecurity, establish an effective land market and thus narrow the income gap between urban and rural residents (Zhou, 2011). The key features of this experiment are: first, that being granted with formal land certificates, farmers can transfer their land to more productive farmers or to private agricultural companies; and second, they can also be employed in these agricultural companies and share the bonuses from increased output.

Besides, to encourage farmers to protect the cultivated land from being converted to non-farm uses, Cultivated Land Protection Fund (CLPF) was given out by the Chengdu government. It should be noted that CLPF was unique to Chengdu City. It was derived from the land transaction revenue of the Chengdu municipal government. To be eligible for the CLPF payment, the land had to be under cultivation. CLPF payment amounted to 360 yuan per $m u^{4}$ per year for basic farmland (to grow field crops such as grain, cotton, oil, and vegetables) and 270 yuan per mu per year for general farmland (used for cash crops like flowers, herbs, etc). In addition, farmers could receive direct subsidy for growing grain which was 60-90 yuan per mu. Therefore, farmers in the certified village could receive up to 450 yuan per mu subsidy from the government. Farmers in the uncertified village, however, do not receive CLPF payments or anything similar. The grain subsidy in the uncertified village was only for households who grew grain over $15 \mathrm{mu}$.

Household incomes were calculated for the 12 months preceding the survey without deducting costs such as farm inputs and daily expenses. As most of these farmers are producing crops primarily for household consumption, if these costs were deducted, their net incomes would be close to zero, as the interviewees complained.

Five hypotheses are to be tested in this paper based on the fieldwork data:

H1: The RLRC program enables certified farmers to participate more in land rental market;

H2: By leasing in land, farms may achieve economies of scale, and therefore obtain higher farm income;

H3: Being freed from land by leasing out farm plots, farmers are able to devote themselves to non-agricultural activities, thus raising their wage income;

H4: The RLRC program helps to increase total household income;

H5: The RLRC program helps to improve the living conditions and quality of life of rural households by increasing per capita income.

\subsection{Estimating treatment effects}

To estimate the impact of the RLRC program on the household income, the households' likelihood of participation in land rental market is firstly estimated through a linear probability model (Wooldridge, 2006, p. 253):

$\mathrm{P}(\mathrm{R}=1 \mid \mathrm{X})=\alpha_{0}+\alpha_{1} D+\alpha_{2} X+\varepsilon$

where $\mathrm{R}$ is the dummy that is equal to 1 if household is participating in land rental market either through leasing in or leasing out some land, and 0 otherwise. $\mathrm{D}$ represents the land tenure status (1-certified, 0 -uncertified). $\mathrm{X}$ is a vector of household/land variables. $a_{1}, a_{2}$ are the parameters of interest, and capture the partial effects of the variables on the farmer's land market participation.

The impacts of land certification program on income sources are estimated through both ordinary least squares (OLS) regression and propensity score matching methods, which are two basic methods for adjusting estimates of causal effects. The goal of both methods is to construct comparison of treated and control units that are balanced in household

\footnotetext{
3 jin: Chinese unit of weight, $1 \mathrm{~kg}=2$ jin.

${ }^{4} \mathrm{mu}$ : Chinese unit of area, 1 hectare $=15 \mathrm{mu}$.
} 
socioeconomic covariates except for land tenure status.

\subsubsection{OLS regression model}

The parameters estimated by the OLS model are based on Cobb-Douglas function:

$I=\beta_{0}+\beta_{1} D+\sum \beta_{2} X+u$

where I denotes the income categories: farm income, wage income, transfer income, total household income, and per capita income. $\beta_{1}$ captures the tenure effect on income sources, which is the average treatment effect over all observations. $\beta_{2}$ represents the impact of household variables on household income.

\subsubsection{Matching model}

The goal of matching is to measure the causal effect of a binary (0-1) treatment or policy on the average outcome variable, i.e. average treatment effects (Wooldridge, 2006, p. 458). The two mostly studied average causal effects in the treatment effects context are the average treatment effects over all observations (ATE), and the average treatment effects on the treated (ATT). By conditioning on observed covariates, $X$, the two treatment effects can be estimated by (Sekhon, 2011):
$A T E=E\left(Y_{i 1} \mid D_{i}=1\right)-E\left(Y_{i 0} \mid D_{i}=0\right)$
[3]
$A T T=E\left(Y_{i 1} \mid D_{i}=1\right)-E\left(Y_{i 0} \mid D_{i}=1\right)$
[4]

Equation 4 cannot be directly estimated because the outcome of certified households if they had not participated in the RLRC program i.e., $\left.E\left(Y_{i 0} \mid D_{i}=1\right)\right)$, is not observed for the treated. Therefore, the matching methods involve the construction of counterfactual expectations of the dependent variable, i.e., constructing estimates of $E\left(Y_{i 0} \mid D_{i}=1\right)$ for the mean outcome of certified households if they had not participated in the RLRC program. ATT is then actually estimated by averaging over the observed outcome values of $Y$ for households that are similar on the covariates $X$ :

$$
A T T=E\left\{E\left(Y_{i} \mid X_{i}, D_{i}=1\right)-E\left(Y_{i} \mid X_{i}, D_{i}=0\right) \mid D_{i}=1\right\}
$$

where the right-hand side is the estimate of the ATE adjusted for the conditional treatment effect among the distribution of covariates $X$ in the treated group (Sekhon, 2011). If causal effects are constant over each observation, then the ATE and ATT are identical (Ho, Imai, King, \& Stuart, 2007).

The matching estimators based on propensity score are widely used to estimate treatment effects. Rosenbaum and Rubin (1983) defined the propensity score as the conditional probability of assignment to a treatment given a vector of covariates $X$ including the values of all treatment confounders:
$P(X)=\operatorname{Pr}(D=1 \mid X)$

After running a probit of household characteristics on tenure status, a propensity score is obtained for each household. This score is the predicted probability of being treated (whether or not actually treated), allowing households to be matched using this score that represents observable characteristics of the household. A better procedure of aftermatching analysis is to use the same parametric analysis as have been used to analyze the original raw data set without pre-processing (Ho, et al., 2007). Therefore, least square estimates were chosen in matching model.

\section{Empirical results}

\subsection{Data description}

Table 1 presents a summary of statistics on the variables for which data was collected from the two villages, as well as test statistics on the equality of means between the villages.

Table 1. Descriptive Statistics for Survey Sample

\begin{tabular}{lcccc}
\hline \multicolumn{1}{l}{ Variables } & Total & $\begin{array}{c}\text { Qun'an } \\
\text { (certified) }\end{array}$ & $\begin{array}{c}\text { Xiayong } \\
\text { (uncertified) }\end{array}$ & $\begin{array}{c}\text { Difference: } \\
\mathrm{t} \text { test }(\mathrm{p} \text { value) }\end{array}$ \\
\hline Characteristics of household head and the household & 53.12 & 53.16 & & \\
Age & 0.94 & 0.91 & 53.07 & $-0.05(0.95)$ \\
Gender & 2.38 & 2.48 & 0.97 & $1.35(0.17)$ \\
Education & 4.38 & 4.27 & 2.27 & $-1.86(0.06) \cdot$ \\
Household size & & 4.50 & $0.75(0.45)$ \\
& & & &
\end{tabular}




\begin{tabular}{lcccc} 
Number of adults (14<age<65) & 3.53 & 3.15 & 3.95 & $3.32(0.001)^{* * *}$ \\
Number of migrant workers & 2.23 & 1.91 & 2.58 & $3.01(0.003)^{* *}$ \\
Characteristics of land & & & & -- \\
Hold a new land certification & 0.52 & 1 & 0 & $-\mathbf{2 . 2 0}(0.03)^{*}$ \\
Land area (mu) & 4.16 & 4.48 & 3.81 & $-10.04(0.000)^{* * *}$ \\
Participation in land transfer: & 0.47 & 0.78 & 0.13 & $0.16(0.86)$ \\
Lease in & 0.10 & 0.09 & 0.10 & $-13.16(0.000)^{* * *}$ \\
Lease out & 0.40 & 0.75 & 0.02 & $-0.40(0.68)$ \\
Income sources (yuan) & & & & $0.47(0.63)$ \\
Farm income & 6,123 & 6,925 & 5,250 & $-11.62(0.000)^{* * *}$ \\
Wage income & 25,624 & 24,514 & 26,833 & $-7.33(0.000)^{* * *}$ \\
Transfer income & 1,898 & 3,640 & 0 & $-14.61(0.000)^{* * *}$ \\
Rent income & 1135 & 2,177 & 0 & $-1.46(0.14)$ \\
Subsidy & 763 & 1,463 & 0 & $-0.50(0.61)$ \\
Other income & 125 & 184 & 60 & $-0.82(0.41)$ \\
Total income & 33,766 & 35,256 & 32,143 & \\
Per capita income & 8,190 & 9,031 & 7,273 & 67 \\
\hline Observations & 140 & 73 & & \\
\hline
\end{tabular}

Significance code: $0.001^{\star \star \star}, 0.01^{\star \star}, 0.05^{*}, 0.10$.

Source: Author's Survey in 2011.

There are not significant differences between villages in terms of the household head's age (average 53 years) and gender (over 90\% male), and the household size (average 4 members). However, the uncertified village averages nearly 1 additional adult and 1 extra migrant worker.

Although the average education level in both villages is at the "primary school" level, the average is higher in the certified village; this difference is statistically significant at $10 \%$ level. The mean land area per household is $4.48 \mathrm{mu}$ in the certified village and $3.81 \mathrm{mu}$ in the uncertified. In both villages, land area per capita ranged from 0.7 to $1.3 \mathrm{mu}$.

As to income variables, the average household has a total income of around 34,000 yuan per year, composed of farm income (18\%), wage income (76\%), and transfer income (6\%). In both villages, wage income is clearly more important as a source of income than the other two sources. The two study sites differ in transfer income. Some $78 \%$ of the certified households engage in land transfer activities: $96 \%$ of these lease the land out to others. Farmers in Qun'an village receive transfers amounting to 3,640 yuan per household. Farmers in the uncertified village, however, rarely lease their land. Of the 67 households in Xiayong, only 9 (13\%) participate in land transfers: 7 lease in land for a rent (100-390 yuan per year per $\mathrm{mu}$ ), and the other 2 allow their relatives to farm the land without charge. Therefore, the average transfer income of the uncertified households is 0.

\subsection{Econometric results}

\subsubsection{Effect of land certification on land market participation}

Table 2 tests Hypothesis 1 based on a probit regression model. The clear result is that the land certification program has a positive and significant (at $0.1 \%$ level) impact on household participation in land transfer activities, especially leasing out the land. Hypothesis 1 is therefore strongly supported.

Table 2. Probability of Participating in Land Market $(n=140)$

\begin{tabular}{lccc}
\hline Variables & $\begin{array}{c}\text { Participation in land } \\
\text { leasing (in or out) }\end{array}$ & Lease-out & Lease-in \\
\hline (Intercept) & $-0.593(1.340)$ & $-2.672(1.474) \cdot$ & $1.016(1.694)$ \\
Hold a new land certification & $1.502(0.298)^{\star * *}$ & $2.477(0.414)^{\star * *}$ & $-0.617(0.404)$ \\
Age & $-0.013(0.015)$ & $-0.021(0.017)$ & $-0.008(0.019)$ \\
Gender & $0.020(0.614)$ & $0.911(0.627)$ & $-0.631(0.578)$ \\
Education & $0.033(0.209)$ & $0.168(0.234)$ & $-0.110(0.284)$ \\
Household size & $-0.095(0.166)$ & $-0.029(0.187)$ & $-0.228(0.238)$ \\
Number of adults & $-0.270(0.195)$ & $-0.158(0.220)$ & $0.032(0.246)$ \\
\hline
\end{tabular}




\begin{tabular}{|c|c|c|c|}
\hline \multicolumn{4}{|l|}{$(14<$ age<65) } \\
\hline Number of migrant workers & $-0.018(0.159)$ & $-0.015(0.188)$ & $-0.442(0.210)$ * \\
\hline Land area $(\mathrm{mu})$ & $0.423(0.154)^{\star \star}$ & $0.351(0.163)^{*}$ & $0.239(0.177)$ \\
\hline AIC & 135.73 & 102.63 & 96.28 \\
\hline
\end{tabular}

Source: Author's Survey in 2011. Standard errors are in parentheses.

The number of migrant workers is statistically significant at $5 \%$ level and with a negative sign. If more household members work outside the village, fewer are available to work on the farm and it is less possible for the household to lease in land.

The land area held by households has a positive and significant effect on land market participation, particularly leasing out of land. As the survey data shows, only $75 \%$ of the total land area in the sample was used to grow rice. Therefore, households with a larger land area may have extra land to lease out.

\subsubsection{OLS regression estimates}

The treatment effects were firstly estimated with the OLS regression model. Table 3 provides the regression results for all the five outcome variables.

\subsubsection{Land tenure status and incomes}

As Table 3 shows, holding a new certification significantly improves transfer income because of the rental income and the CLPF given out in the certified village. In the certified village, transfer income contributes up to $10 \%$ of the total household income.

However, secure land tenure does not have a discernible impact on other income sources. There could be two explanations for this result:

1. Reinforcing property rights of the farmers by land certification program, together with the matching support of the village leaders' efforts to attract investment, has a substitution effect which boosts farmers' participation in land transferring activities instead of farming or being employed. This can be confirmed by the probit results. In return, households obtain rental income which is determined by the lessees' performance in the current year. This rental income raises welfare since farmers save on effort they might otherwise expend on farming or working in non-farm activities. The results from column 4 and 5 support the conjecture that leasing is contributing to household income.

2. An income effect may exist if a household receives transfer income which is large enough to discourage them from using effort to farm or take up wage employment in the cities. The income effect could increase the household's demand for leisure.

Land tenure status can only raise a household's transfer income on the condition that the household can transfer the land to more productive farmers or private agricultural businesses. This will largely depend on the plot location, and most importantly, the village committee's ability to attract investments in agricultural business.

While conducting the survey, we learnt that those farmers who do not lease out their land, which is largely due to a limited land market, continue to farm to supplement their income, even when they do not obtain a corresponding return from land compared to their labour input and other farm-related inputs. The high living costs and instability of employment opportunities in urban areas compels them to cultivate. For them, farming is like having insurance against the volatile wage income from urban cities. For farmers who leased out their land, especially those who leased out all of their land, the problem is how to make sure they obtain the transfer income in time. In some villages in Chengdu city, it is not unusual for private enterprises to quit in the middle of contracts without paying rent to farmers (Han, 2009). In the village surveyed, 11 households had not received rent because of the poor performance of the plantations.

The contribution of land certification to incomes could also be constrained by the short time lapse between the time when land certificates were issued and when the survey was conducted. The RLRC program had been in effect in Qun'an village for just about 2 years at the time of survey, thus the insignificance of tenure dummy on non-transfer incomes may be due to the limited time for the effect of tenure on income to materialize. 
Table 3. Regression Results for Household Incomes ( $n=140)$

\begin{tabular}{|c|c|c|c|c|c|}
\hline Model & 1 & 2 & 3 & 4 & 5 \\
\hline & $\begin{array}{c}\text { Farm } \\
\text { income }\end{array}$ & $\begin{array}{l}\text { Wage } \\
\text { income }\end{array}$ & $\begin{array}{l}\text { Transfer } \\
\text { income }\end{array}$ & $\begin{array}{c}\text { Total } \\
\text { income }\end{array}$ & $\begin{array}{l}\text { Per capita } \\
\text { income }\end{array}$ \\
\hline (Intercept) & $\begin{array}{c}11474.825 \\
(0.169)\end{array}$ & $\begin{array}{c}-37410.234 \\
(-0.559)\end{array}$ & $\begin{array}{c}-4169.364 \\
(-0.948)\end{array}$ & $\begin{array}{c}-30943.936 \\
(-0.324)\end{array}$ & $\begin{array}{c}9991.372 \\
(0.281)\end{array}$ \\
\hline tenure & $1225.512(0.178)$ & $\begin{array}{c}1199.047 \\
(0.177)\end{array}$ & $\begin{array}{l}1667.792 \\
(3.749)^{* * *}\end{array}$ & $\begin{array}{c}4097.744 \\
(0.425)\end{array}$ & $\begin{array}{c}666.670 \\
(0.185)\end{array}$ \\
\hline age & $\begin{array}{c}-602.701 \\
(-0.243)\end{array}$ & $\begin{array}{c}782.283 \\
(0.320)\end{array}$ & $\begin{array}{c}102.210 \\
(0.636)\end{array}$ & $\begin{array}{c}295.263 \\
(0.085)\end{array}$ & $\begin{array}{c}-347.513 \\
(-0.267)\end{array}$ \\
\hline $\operatorname{age}^{\wedge} 2$ & $6.382(0.270)$ & $\begin{array}{c}-3.391 \\
(-0.146)\end{array}$ & $\begin{array}{c}-0.749 \\
(-0.491)\end{array}$ & $\begin{array}{c}2.255 \\
(0.068)\end{array}$ & $\begin{array}{c}4.325 \\
(0.350)\end{array}$ \\
\hline gender & $7094.886(0.742)$ & $\begin{array}{c}-12762.885 \\
(-1.357)\end{array}$ & $\begin{array}{c}-101.126 \\
(-0.164)\end{array}$ & $\begin{array}{c}-5562.618 \\
(-0.415)\end{array}$ & $\begin{array}{c}1687.803 \\
(0.337)\end{array}$ \\
\hline education & $\begin{array}{c}-1215.923 \\
(-0.326)\end{array}$ & $\begin{array}{c}3013.774 \\
(0.823)\end{array}$ & $\begin{array}{c}157.851 \\
(0.655)\end{array}$ & $\begin{array}{c}2046.300 \\
(0.392)\end{array}$ & $\begin{array}{l}-15.721 \\
(-0.008)\end{array}$ \\
\hline household size & $\begin{array}{c}-916.470 \\
(-0.306)\end{array}$ & $\begin{array}{c}2587.731 \\
(0.879)\end{array}$ & $\begin{array}{c}-539.301 \\
(-2.787)^{* *}\end{array}$ & $\begin{array}{c}1128.256 \\
(0.269)\end{array}$ & $\begin{array}{c}-1595.240 \\
(-1.019)\end{array}$ \\
\hline adults & $3603.839(0.979)$ & $\begin{array}{c}-771.580 \\
(-0.213)\end{array}$ & $\begin{array}{c}125.963 \\
(0.529)\end{array}$ & $\begin{array}{c}2926.440 \\
(0.567)\end{array}$ & $\begin{array}{c}1981.128 \\
(1.028)\end{array}$ \\
\hline $\begin{array}{l}\text { migrant } \\
\text { labourers }\end{array}$ & $\begin{array}{c}-1645.090 \\
(-0.652)\end{array}$ & $\begin{array}{l}11052.784 \\
(4.452)^{\star * \star}\end{array}$ & $\begin{array}{l}110.986 \\
(0.680)\end{array}$ & $\begin{array}{l}9581.347 \\
(2.706)^{\star \star}\end{array}$ & $\begin{array}{c}1405.178 \\
(1.064)\end{array}$ \\
\hline land area & $\begin{array}{c}-1491.172 \\
(-0.668)\end{array}$ & $\begin{array}{c}290.143 \\
(0.132)\end{array}$ & $\begin{array}{c}606.862 \\
(4.202)^{* * *}\end{array}$ & $\begin{array}{c}-671.582 \\
(-0.214)\end{array}$ & $\begin{array}{c}-1046.650 \\
(-0.896)\end{array}$ \\
\hline lease in land & $\begin{array}{l}27055.866 \\
(3.650)^{\star * *}\end{array}$ & $\begin{array}{c}-2621.967 \\
(-0.360)\end{array}$ & $\begin{array}{c}-780.607 \\
(-1.629)\end{array}$ & $\begin{array}{c}23771.117 \\
(2.286)^{*}\end{array}$ & $\begin{array}{c}11091.726 \\
(2.859)^{* *}\end{array}$ \\
\hline lease out land & $5119.819(0.755)$ & $\begin{array}{c}3245.958 \\
(0.487)\end{array}$ & $\begin{array}{l}2198.608 \\
(5.014)^{\star * *}\end{array}$ & $\begin{array}{c}10799.045 \\
(1.135)\end{array}$ & $\begin{array}{c}5522.496 \\
(1.556)\end{array}$ \\
\hline $\mathbf{R}^{2}$ & 0.12 & 0.37 & 0.66 & 0.21 & 0.10 \\
\hline
\end{tabular}

Values of t-statistics are reported in parenthesis.

Significance code: $0.001^{\star * *}, 0.01^{\star *}, 0.05^{*}, 0.1$.

Source: Authors' Survey in 2011.

\subsubsection{Non-farm employment and household income}

Non-farm employment has strongly demonstrated its importance in improving household income. As is shown in Table 1, over $60 \%$ of the adults in both villages work in non-agricultural sectors out of the village; the proportion of total household income derived from wage income accounts for $70 \%$ in the certified village, and $83 \%$ in the uncertified.

The impacts of the number of migrant labourers on wage income and total income are positive and significant (see Table 3). With one more migrant labourer employed in the non-agricultural sector, the household's annual wage income would increase by 11,052 yuan, and total income rises 9,581 yuan. All these indicate the increasing importance of wages in household income growth.

\subsubsection{Land market participation and incomes}

Participation in the land rental market has manifested its importance in raising household income. Households who leased out land may gain 2,198 yuan more transfer income than those who did not.

Compared to households who did not lease in land, households that did so achieved 27,055 yuan more farm income, 23,771 yuan more total household income and 11,091 yuan more per capita income. This may be due to the fact that land was transferred to more productive farmers and economy of scale was reached. The above evidence supports Hypothesis 2. 


\subsubsection{Other determinants of income variables}

The positive and significant effect of land area on transfer income is plausible since a title (certificate) allows the household to receive transfer income in proportion to the size of their holding.

Household size has a statistically significant and negative impact on transfer income per household. For extra member, a household would receive 539 yuan less transfer income. The reason that larger household size does not help to obtain more transfer income may be that transfer income was given out according to land area rather than household size.

\subsubsection{Matching estimates}

The matching model gives the bias-adjusted estimates that correct the within-match mean differences in the outcome variables.

One of the most common and easiest matching algorithms to implement is $\mathrm{k}$ : 1 nearest neighbour matching (Rubin, 1973). It matches control individuals to the treated group and discards controls that are not selected as matches. Since there are fewer control individuals (67) comparable to the treated individuals (73) in the sample, the matching method is implemented with replacement (Dehejia \& Wahba, 2002), which means control individual can be used as matches for more than one treated individual.

Table 4. Matching Estimates of Treatment Effects of RLRC Program on Household Income

\begin{tabular}{|c|c|c|c|}
\hline \multirow{2}{*}{ Income sources } & \multicolumn{2}{|c|}{ Matching } & \multirow{2}{*}{ OLS } \\
\hline & ATT & ATE & \\
\hline Farm income & $2918.1(0.29)$ & $1331.9(0.24)$ & $1225.51(0.17)$ \\
\hline Wage income & $5991.6(0.53)$ & $5837.8(0.73)$ & $1199.04(0.17)$ \\
\hline Transfer income & $3639.7(4.79)^{\star * \star}$ & $2679.7(5.57)^{\star * \star}$ & $1667.79(3.74)^{\star \star \star}$ \\
\hline Total income & $12721(0.88)$ & $10001(1.05)$ & $4097.74(0.42)$ \\
\hline Per capita income & $4218.9(0.82)$ & $1977.7(0.67)$ & $666.67(0.18)$ \\
\hline
\end{tabular}

Note: Results are estimated by R software. Matching based on 5:1 with replacement achieved better improvement and higher common support compared to $k=1 \ldots 4$. So we chose $5: 1$ nearest neighbour matching.

Significance code: $0.001^{\star \star *}, 0.01^{* *}, 0.05 *, 0.1$.

Source: Author's Survey in 2011. Numbers in parentheses are t ratios.

The OLS regression from Table 3 is also provided as a benchmark in Table 4. The models of matching yield similar patterns of statistical significance to the OLS estimates. Both methods agree that the land certification program has significantly increased households' transfer income only.

Overall, the average treatment effect on the treated (ATT) exceeds the average treatment effect over all observations (ATE), and both are larger than the OLS estimates, which represents an estimate of the ATE. As can be seen, after discarding the unmatched data, the causal effects become stronger than those in the regression model.

\section{Conclusion}

This paper has attempted to demonstrate two main points: land certification encourages farmers to participate in land market and improves household incomes.

The impact of land tenure security on land market participation has been confirmed: the land certification program encourages farmers to engage more in land transferring activities, especially leasing out land to plantations or more productive farmers.

However, the average household income or per capita income on certified plots was no greater than that on the uncertified. Reasons for this include the fact that land certification may have a substitution effect and an income effect: if households engage in the land market to earn rental income, as confirmed above, they may save on the effort they otherwise would have expended on farming or working in non-farm activities; if the cash transfer plus land rentals are large enough, the farmers may rely on this source of income and enjoy more leisure. 
In addition, leasing in land for farming contributes significantly to raising the total income and per capita income of the households. This supports the proposition that farmers are using the farmland more efficiently, and that benefits of economies of scale are being realised. Those who had comparative advantages in farming tend to lease in land, while those who had comparative advantages in off-farm employment tend to lease out land.

Two policy implications can be drawn from these findings.

1. Wage income from migrant workers is the main source of income for rural households. Therefore, lowering the risk of wage employment would encourage more workers to move to the formal sector, improve rural household income, and at the same time release more land for large-scale agriculture.

The challenge for policymakers is to attract investors and industries to their cities that provide more job opportunities with greater income security, and thus absorb the surplus rural labour. Therefore, security of tenure has to be complemented with security of wage income if farm consolidation is to take place on a larger scale.

2. The effect of tenure security on household income is not significant except for transfer income. However, subsidies in the form of transfer income from the government and income derived from land rent cannot be a permanent solution. Some commentators warn that farmers could lose their land once they were allowed to lease it out and thus in the process lose the guarantee of their livelihood (Xuefeng $\mathrm{He}, 2010)$. Thus income security and livelihood opportunities remain a challenge for the foreseeable future. Consequently, the introduction of the RLRC program in other places must be closely scrutinized for all its effects before it is expanded to the rest of the country.

\section{References}

Chand, S., \& Yala, C. (2009). Land Tenure and Productivity: Farm-Level Evidence from Papua New Guinea. Land Economics, 85(3), 442-453.

ChinaDaily. (2013). China Raises State Procurement Price for Rice, from http://www.chinadaily.com.cn/business/201301/30/content_16188472.htm

de Janvry, A., Gordillo, G., Platteau, J. P., \& Sadoulet, E. (2001). Access to Land, Rural Poverty and Public Action: Oxford University Press, Oxford, UK.

Dehejia, R. H., \& Wahba, S. (2002). Propensity Score-Matching Methods for Nonexperimental Causal Studies. The Review of Economics and Statistics, 84(1), 151-161. doi: 10.2307/3211745

Deininger, K., Ali, D. A., \& Alemu, T. (2011). Impacts of Land Certification on Tenure Security, Investment, and Land Market Participation: Evidence from Ethiopia. Land Economics, 87(2), 312.

Deininger, K., \& Chamorro, J. S. (2002). Investment and Income Effects of Land Regularization: The Case of Nicaragua. Policy Research Working Paper Series.

Dong, X.-Y. (2000). Public Investment, Social Services and Productivity of Chinese Household Farms. The Journal of Development Studies 36(3), (February 1): 100-122.

Fan, M. (2008). China to Allow Land Leasing, Transfer, from http://www.washingtonpost.com/wpdyn/content/article/2008/10/19/AR2008101901532.html?hpid=artslot

FAO. (2002). FAO Land Tenure Studies 3 - Land Tenure and Rural Development, from http://www.fao.org/DOCREP/005/Y4307E/y4307e00.htm

Feder, G., \& Nishio, A. (1998). The Benefits of Land Registration and Titling: Economic and Social Perspectives. Land Use Policy, 15(1), 25-43.

Feder, G., \& Onchan, T. (1987). Land Ownership Security and Farm Investment in Thailand. American Journal of Agricultural Economics, 69(2), 311-320.

Gine, X. (2005). Cultivate or Rent Out? Land Security in Rural Thailand (Vol. World Bank Policy Research Working Paper 3734): The World Bank.

Han, Y. (2009). 在 自己 土 地上 打 エ [Being Employed on Their Own Land], from http://newsweek.inewsweek.cn/magazine.php?id=4466

He, X. (2010). 地权的逻辑 : 中国农村土地制度向何处去[The Logic of Land Rights:Which Direction Should Be China's Land System towards]: 中国政法大学出版社[China University of Political Science and Law Press].

$\mathrm{He}, \mathrm{X} .(2011)$. 国家统计局数据显示我国城乡收入差距正在缩小[Data From the National Bureau of Statistics Shows that the Urban-rural Income Gap is Narrowing], from http://www.ce.cn/xwzx/gnsz/gdxw/201110/20/t20111020_22773827.shtml

Ho, D. E., Imai, K., King, G., \& Stuart, E. A. (2007). Matching as Nonparametric Preprocessing for Reducing Model Dependence in Parametric Causal Inference. Political Analysis, 15(3), 199-236.

Holden, Deininger, K., \& Ghebru, H. (2011). Tenure Insecurity, Gender, Low-cost Land Certification and Land Rental Market Participation in Ethiopia. Journal of Development Studies, 47(1), 31-47. doi: 10.1080/00220381003706460

Holden, S., Deininger, K., \& Ghebru, H. (2009). Impacts of Low-Cost Land Certification on Investment and Productivity. American 
Journal of Agricultural Economics, 91(2), 359.

Holden, S. T., \& Ghebru, H. (2011). Household Welfare Effects of Low-cost Land Certification in Ethiopia, CLTS Working Papers No 3/11, from http://swopec.hhs.se/nlsclt/abs/nlsclt2011_003.htm

López, R. (1996). Land Titles and Farm Productivity in Honduras: Department of Agricultural and Resource Economics,University of Maryland, College Park, MD.

Place, F., \& Otsuka, K. (2002). Land Tenure Systems and Their Impacts on Agricultural Investments and Productivity in Uganda. Journal of Development Studies, 38(6), 105-128.

Rosenbaum, P. R., \& Rubin, D. B. (1983). The Central Role of the Propensity Score in Observational Studies for Causal Effects. Biometrika, 70(1), 41-55.

Rubin, D. B. (1973). Matching to Remove Bias in Observational Studies. Biometrics, 29(1), 159-183. doi: 10.2307/2529684

Sekhon, J. S. (2011). Multivariate and Propensity Score Matching Software with Automated Balance Optimization: The Matching Package for R. Journal of Statistical Software, 42(7), 1-52.

Wooldridge, J. M. (2006). Introductory Econometrics: A Modern Approach (3rd ed.).

Zhang, X. (2010). China Targets Rural Issues in 9 Consecutive No. 1 Central Documents, from http://english.cri.cn/6909/2012/02/01/2021s678717.htm

Zhou, Q. (2011). 土地制度改革的成都路径 [The Chengdu Experience of Rural Land Tenure Reform], from http://economy.caing.com/2011-01-24/100220639.html 